\title{
PENGARUH MANAJEMEN SARANA PRASARANA DAN KOMPETENSI PROFESIONALITAS GURU TERHADAP PENERIMAAN PESERTA DIDIK BARU MTSN 8 JOMBANG
}

\author{
SITI HUSNUL CHOTIMAH \\ MTsN 8 Jombang Jawa Timur \\ Chotimah.3007@gmail.com
}

\begin{abstract}
ABSTRAK
Penelitian ini bertujuan untuk mengetahui secara empiris pengaruh manajemen sarana dan kompetensi profesionaltas guru terhadap penerimaan siswa baru, dimana sebelumnya diidentifikasi secara parsial, baik pengaruh manajemen sarana maupun pengaruh kompetensi profesionalitas guru terhadap penerimaan peserta didik baru. Dalam penelitian ini penulis menggunakan data kuantitatif formula statistika yang digunakan adalah rumus persamaan regresi linear berganda, karenavariabel bebas pada penelitian ini adalah ganda atau dua. Akhirnya, penelitian ini menemukan sebuah kesimpulan bahwa secara simultan manajemen sarana prasarana dan kompetensi profesionalitas guru berpengaruh secara signifikan terhadap penerimaan peserta didik baru dengan hasil uji F sebesar 145,0 yang dikonsultasikan kepada F-tabel, F-tabel 145 $>$ 3,33. Adapun Sarana prasarana pengaruh secara signifikan terhadap penerimaan peserta didik baru dengan pembuktian uji $t$, dimana $r$ hitung lebih besar dari pada $r$ tabel 0,385 > 0.339. Begitu juga kompetensi profesionalitas guru berpengaruh secara signifikan terhadap penerimaan peserta didik baru dengan hasil uji tsebesar 7,373 > 0.339. Dengan demikian dapat dikemukakan bahwa managemen sarana prasarana dan kompetensi guru sangat berpengaruh terhadap penerimaan peserta didik baru MTsN 8 jombang tahun pelajaran 2019-2020.
\end{abstract}

Kata Kunci : Sarana Prasarana, Kompetensi Profesionalitas Guru, Penerimaan Peserta Didik baru

\section{PENDAHULUAN}

Sarana dan prasarana adalah semua benda atau barang yang bergerak maupun yang tidak bergerak digunakan untuk menunjang terlaksanakannya proses pembelajaran yang langsung maupun yang tidak langsung dalam sebuah pendidikan. Dengan adanya manajemen sarana dan prasarana pendidikan akan mampu mendaya gunakan semua sarana dan prasarana pendidikan secara efektif dan efisien,bahwa tujuan manajemen sarana dan prasarana secara umum adalah untuk memberikan layanan secara profesional dibidang sarana dan prasarana pendidikan dalam rangka terselenggarakannya pendidikan secara efektif dan efisien. Menurut UU Nomor 14 Tahun 2005 tentang guru dan dosen Pasal 1:"Guru adalah pendidik profesional dengan tugas utama mendidik, mengajar, membimbing, mengarahkan, melatih, menilai, dan mengevaluasi siswa pada pendidikan anak usia dini jalur pendidikan formal, dasar dan menengah.” Dalam Peraturan Menteri Pendidikan Nasional RI Nomor 16 Tahun 2007 tentang standar kompetensi akademik dan kompetensi guru dijelaskan bahwa: "kualifikasi akademik guru SD/MI, SMP/MTs, dan SMA/MA minimum diploma 4 (D- 
4) atau Sarjana (S-1). Dalam PMPN ini juga disebutkan bahwa: "guru harus menguasai empat kompetensi utama, yaitu pedagogis, kepribadian, sosial dan profesional. Keempat kompetensi ini terintegrasi dalam kinerja guru".

Kompetensi guru sangat diperlukan dalam proses belajar mengajar karena guru merupakan sosok terdepan dalam pelaksanaan pendidikan. Kompetensi yang dimiliki oleh guru merupakan wujud dari pelaksanaan profesinya, yang mana pada dasarnya guru profesional adalah guru yang memiliki keterampilan, kompetitif, cakap dalam pengajaran serta memiliki pribadi yang baik dan mampu melakukan penyesuaian diri dalam masyarakat. Perlu kita sadari kompetensi professional guru sangat penting dalam rangka mewujudkan tujuan pendidikan untuk mencetak siswa yang cerdas dan mampu menjadi penerus generasi yang handal.

Berdasarkan dari penelusuran Penelitian yang berkaitan dengan manajemen sarana dan prasarana telah dilakukan sebelumnya. Harry Pramono (2012) mengatakan. Pengaruh sistem pembinaan terhadap kompetensi guru Frekuensi terbanyak pada guru yang mendapatkan sistem pembinaan baik dan cukup dengan persentase $40,5 \%$, sangat baik $12,5 \%$, dan tidak baik sebanyak 6,8\%. Pengaruh sistem pembinaan terhadap kinerja guru dari hasi penghitungan pada tabel koefisien diperoleh nilai thitung sebesar 2.482 lebih besar dari $\mathrm{t}$ tabel 2.000. Berarti koefisien jalur pengaruh dari sistem pembinaan terhadap kompetensi adalah berarti (ada pengaruh langsung sitem pembinaan terhadap kinerja) dengan kontribusi sebesar $6,00 \%$.

Manajemen sarana adalah suatu kegiatan bagaimana mengatur dan mengelola sarana pendidikan secara efesien dan efektif dalam rangka pencapaian tujuan yang telah ditetapkan. Bahwa manajemen sarana pendidikan bertugas "mengatur dan menjaga sarana pendidikan agar dapat memberikan kontribusi secara optimal dan berarti pada jalannya proses pendidikan". pengelolaan ini meliputi kegiatan perencanaan, pengadaan, pengawasan, penyimpanan inventarisasi dan Penghapusan serta penataan. Manajemen sarana yang baik diharapkan dapat menciptakan sekolah yang bersih, rapi, indah, sehingga dan dapat menciptakan kondisi yang menyenangkan baik bagi guru maupun siswa untuk berada disekolah. Dalam perencanaan, sarana prasarana pendidikan dilaksanakan secara kontinue dan sesuai kebutuhan, untuk perencanaan jangka pendek diadakan satu tahun sekali, untuk jangka menengah (4-5 Tahun), dan untuk jangka panjang (10-15 tahun) atau sesuai dengan kebutuhan sekolah. Yang direncanakan adalah mengenai apa saja kebutuhan atau pemenuhan sarpras sekolah, untuk meningkatan mutu. Yaitu pemenuhan standar sarana prasarana yang dipandang perlu dan dibutuhkan, dan sifatnya jelas untuk mendukung kegiatan proses belajar mengajar, dan sesuai dengan plafon anggaran yang ada. Variabel pada penelitian ini Menejemen Sarana Prasarana Pendidikan dalam Meningkatan Mutu SDM Sedang penelitian sekarang menggunakan metode kuantitatif dg variabel manajemen sapras dan kompetensi guru terhadap penerimaan peserta baru.

\section{METODE PENELITIAN}

Penelitian ini merupakan penelitian kuantitatif. Subyek penelitian adalah guru sedangkan obyek penelitian adalah Sarana prasaran dan dan profesionalitas guru terhadap penerimaan pseserta didik baru di MTsn 8 Jombang. Untuk menjelaskan variabel-variabel penelitian tersebut dilakukan dengan tingkat eksplanasi deskriptif dan 
korelatif. Tingkat eksplanasi deskriptif bertujuan menggambarkan hasil temuan variabel mandiri dari penelitian mengenai sarana prasaran dan dan profesionalitas guru terrhadap penerimaan peserta didik baru di MTsn 8 Jombang. Sedangkan tingkat eksplanasi korelatif dipergunakan untuk mencari hubungan antar variabel sarana prasaran dan dan profesionalitas guru terrhadap penerimaan peserta didik baru di MTsn 8 Jombang. Penelitian ini melibatkan tiga variabel, yakni dua variabel bebas dan satu variabel terikat. Variabel-variabel bebas adalah variabel Sarana dan prasarana (X1) dan variabel profesionalitas guru (X2), sedangkan variabel terikat adalah penerimaan Peserta didik baru(Y) di MTsN 8 Jombang.

Teknik sampling adalah merupakan teknik pengambilan sampel dari populasi yang akan dipergunakan dalam penelitian. ${ }^{61}$. Dalam penelitian ini, subjek yang diteliti sebagai sumber data atau responden adalah semua guru MTsN 8 Jombang tahun ajaran 2019/2020, sebanyak 32 guru yang terdidri dari guru PNS dan non PNS. Variabel sarana prasarana $\left(\mathrm{X}_{1}\right)$ diungkap dengan angket sebanyak 32 buah yang terdiri dari 30 aspek, dengan skala pengukuran 1 s.d 5. Variabel Profesionalisme Guru $\left(\mathrm{X}_{2}\right)$ diungkap dengan angket sebanyak 32 buah yang terdiri dari 30 aspek, dengan skala pengukuran 1 s.d. 5 dan Variabel Penerimaan Peserta Didik Baru ( $\mathrm{X}_{3}$ ),diungkap dengan angket sebanyak 32 butir yang terdiri dari 25 komponen, dengan skala pengukuran 1 s.d. 5 .

\section{HASIL PENELITIAN DAN PEMBAHASAN}

Berdasarkan hasil perhitungan nilai $\mathrm{t}$ dan nilai $\mathrm{F}$ terdapat hubungan yang signifikan pada taraf nyata 5\% oleh karena itu, dari hasil perhitungan uji $\mathrm{t}$ dan uji $\mathrm{F}$ di atas yang dikonsultasikan terhadap t-tabel dan F-tabel dapat diuji hipotesis dengan kesimpulan sebagai berikut:

a. Variabel Sarana Prasarana ( $\mathrm{X}_{1}$ )

Variabel sarana prasarana MTsN 8 di kabupaten Jombang diungkap dengan angket sebanyak 32 buah yang terdiri dari 30 aspek, dengan skala pengukuran 1 s.d. 5, dari hasil penelitian secara keseluruhan didapatkan rata- rata skor 4,109 dengan, rata-rata skor tertinggi 4,90, dan rata- rata skor terendah 3,60. Berdasarkan hasil uji hipotesis pada pengaruh variabel manajemen sarana terhadap Penerimaan Siswa Baru, dengan hasil uji t sebesar 2.420, jika dikonsultasikan kepada t-tabel, maka diketahui bahwa t-hitung lebih besar dari t-tabel 0,385 >0.339, artinya secara parsial manajemen sarana berpengaruh secara signifikan terhadap Penerimaan Siswa Baru.

b. Variabel Profesionalisme Guru $\left(\mathrm{X}_{2}\right)$

Variabel profesionalisme Guru diungkap dengan angket sebanyak 32 buah yang terdiri dari 30 aspek, dengan skala pengukuran 1 s.d. 5, dari hasil penelitian secara keseluruhan didapatkan rata-rata skor 4,57, dan rata-rata skor tertinggi 4,90, dan rata-rata skor terendah 4,00. Berdasarkan hasil uji hipotesis pada pengaruh variabel kompetensi profesionalitas guru terhadap Penerimaan Siswa Baru, dengan hasil uji t sebesar 7,373, jika dikonsultasikan kepada t-tabel, maka diketahui bahwa t-hitung lebih besar dari t-tabel, 7,373 > 0.339, artinya secara parsial kompetensi profesionalitas guru berpengaruh secara signifikan terhadap Penerimaan Siswa Baru. 
c. Variabel Penerimaan Peserta Didik Baru $\left(\mathrm{X}_{3}\right)$

Variabel penerimaan peserta didik diungkap dengan angket sebanyak 32 butir yang terdiri dari 25 komponen, dengan skala pengukuran 1 s.d. 5, dari hasil penelitian secara keseluruhan didapatkan rata-rata skor 4,57dengan rata-rata skor tertinggi 3,4, dan rata-rata skor terendah 3,1.

Berdasarkan hasil uji hipotesis pada pengaruh variabel kompetensi profesionalitas guru terhadap Penerimaan Siswa Baru, dengan hasil uji F sebesar 40,328, jika dikonsultasikan kepada F-tabel, maka diketahui bahwa F-hitung lebih besar dari F-tabel 40,328 > 0,339, artinya secara simultan bahwa manajemen sarana dan kompetensi profesionalitas guru keduanya berpengaruh secara signifikan terhadap Penerimaan Siswa Baru.

\section{Pengaruh Sarana Prasarana terhadap Penerimaan Peserta Didik Baru ( $\left.\mathbf{X}_{1}\right)$}

Dengan menggunakan rumus regresi sederhana:

Keterangan:

$$
\mathrm{r}_{X Y}=\frac{n \sum X-\left(\sum X\right)\left(\sum Y\right)}{\sqrt{\left[\left(n \sum X^{2}-\left(\sum X\right)^{2}\right]\left\{n \sum y^{2}-\left(\sum Y\right)^{2}\right\}\right.}}
$$

$$
\begin{aligned}
\mathrm{rXY} & =\text { koefisien korelasi product moment } \\
\mathrm{X} & =\text { skor tiap butir soal } \\
\mathrm{Y} & =\text { skor tiap responden } \\
\Sigma \mathrm{XY} & =\text { skor Total koefisien korelasi } \\
\Sigma \mathrm{X} & =\text { skor total butir soal } \\
\Sigma \mathrm{Y} & =\text { skor total responden } \\
\mathrm{N} & =\text { banyak responden }
\end{aligned}
$$

$$
\begin{aligned}
& \mathrm{r}_{\mathrm{X} 1 \mathrm{Y}}=\frac{n \sum X 1 Y-\left(\sum X 1\right)\left(\sum Y\right)}{\sqrt{\left[\left(n \sum X 1^{2}\right)-\left(\sum X 1\right)^{2}\right]\left\{n \sum y^{2}-\left(\sum Y\right)^{2}\right\}}}
\end{aligned}
$$

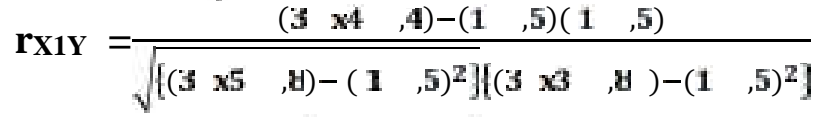

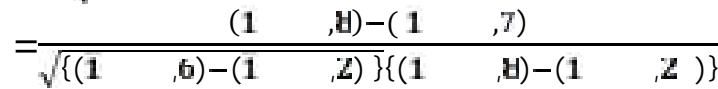

$$
\begin{aligned}
& =\frac{-3, y}{\sqrt{\{(1,4) \times(5,5)\}}} \\
& =\frac{-3, y}{\sqrt{7 \quad, 1}}=\frac{-3, y}{\mathbf{B}, 3}=0,385
\end{aligned}
$$

Jadi: $\mathrm{r}$ hitung $=0,385$ dan $\mathrm{r}$ tabel $5 \%=0,339$

Berdasarkan hasil perhitungan di atas membuktikan bahwa ada pengaruh yang signifikan sarana prasarana terhadap penerimaan peserta didik baru MTs Negeri 8 Jombang, dengan koefisien korelasi sederhana di peroleh $\mathrm{r}$ hitung sebesar 0,385 dan $\mathrm{r}$ tabel sebesar 0,339 atau koefisien determinasinya $13749031,52 \%$, yang berarti bahwa baik tidaknya sarana prasarana pendidikan sangat berpengaruh terhadap penerimaan peserta didik baru, semakin baik sarana prasarana akan meningkatkan jumlah penerimaan peserta didik baru dan sebaliknya jika sarana prasarana pendidikan kurang baik, maka penerimaan 
peserta didik baru juga menurun. Hasil penelitian ini sesuai dengan penelitian yang dilakukan Epuji Astuti (2018 : 45,) dalam tesisnya yang berjudul perencanaan sarana prasarana sekolah dalam meningkatkan mutu SDM di MAN 3 Madiun bahwa kegiatan pendidikan pada hakekatnya adalah harus di tunjang dengan kelengkapan sarana prasarana yang ada.

\section{Pengaruh Profesionalisme Guru terhadap Penerimaan Peserta Didik Baru $\left(\mathrm{X}_{2}\right)$}

Dengan menggunakan rumus regresi sederhana:

Keterangan:

$$
\mathrm{r}_{\mathrm{XY}}=\frac{n \sum X-\left(\sum X\right)\left(\sum Y\right)}{\sqrt{\left[\left(n \sum X^{2}-\left(\sum X\right)^{2}\right]\left\{n \sum y^{2}-\left(\sum Y\right)^{2}\right\}\right.}}
$$

rXY = koefisien korelasi product moment

$\mathrm{X}=$ skor tiap butir soal

$\mathrm{Y}=$ skor tiap responden

$\Sigma \mathrm{XY}=$ skor Total koefisien korelasi

$\Sigma \mathrm{X}=$ skor total butir soal

$\sum \mathrm{Y}=$ skor total responden

$\mathrm{n}$ = banyak responden

$$
\begin{aligned}
& \mathrm{r}_{\mathrm{X} 2 Y}=\frac{n \sum X 2 Y-\left(\sum X 2\right)\left(\sum Y\right)}{\sqrt{\left[\left(n \sum X 2^{2}\right)-\left(\sum X 2\right)^{2}\right]\left\{n \sum y^{2}-\left(\sum Y\right)^{2}\right\}}}
\end{aligned}
$$

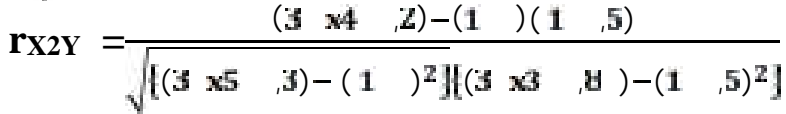

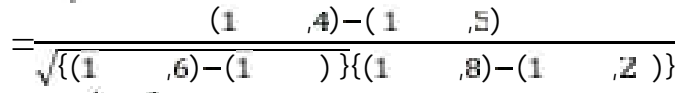

$$
\begin{aligned}
& =\frac{-4,1}{\sqrt{\{(-1,4) \times(5,5)\}}} \\
& =\frac{-4 \quad, 1}{\sqrt{-5 \quad, 8}} \\
& =\frac{-5 \quad, 1}{7,8}=7,373 \\
& \text { Jadi: } \mathrm{r} \text { hitung }=7,373 \text { dan } \mathrm{r} \text { tabel } 5 \%=0,339
\end{aligned}
$$

Berdasakan hasil perhitungan di atas membuktikan bahwa ada pengaruh yang signifikan profesionalisme guru terhadap penerimaan peserta didik baru di MTsN 8 Jombang dengan koefisien korelasi sederhana di peroleh $r$ hitung sebesar 7,373 dan $\mathrm{r}$ tabel sebesar 0,339 atau koefisien determinasinya sebesar $13749031,52 \%$, yang berarti bahwa profesionalisme guru berpengaruh terhadap baik tidaknya penerimaan peserta didik baru di MTsN 8 Jombang, semakin baik kinerja Guru akan meningkatkan penerimaan peserta didik baru dan sebaliknya jika kinerja guru kurang baik, maka penerimaan peserta didik baru juga akan rendah pula. Hasil penelitian ini sesuai dengan pendapat (Cut Fitriani,2012: 53) dalam jurnalnya yang berJudul: kompetensi profesional guru dalam pengelolaan pembelajaran di MTs Muhamadiyah Banda Aceh jika guru memiliki kinerja yang 
baik akan dapat mengelola sumberdaya manusia termasuk pesertadidik yang ada di madrasah tersebut menjadi baik pula.

\section{Pengaruh Secara Simultan Sarana Prasarana dan Profesionalisme Guru terhadap Penerimaan Peserta Didik Baru ( X3)}

Dengan menggunakan rumus regresi sederhana:

$$
\begin{aligned}
& \mathrm{r}_{\mathrm{XY}}=\frac{n \sum X-\left(\sum X\right)\left(\sum Y\right)}{\sqrt{\left[\left(n \sum X^{2}-\left(\sum X\right)^{2}\right]\left\{n \sum y^{2}-\left(\sum Y\right)^{2}\right\}\right.}} \\
& \text { rXY = koefisien korelasi product moment } \\
& \mathrm{X}=\text { skor tiap butir soal } \\
& \mathrm{Y}=\text { skor tiap responden } \\
& \Sigma X Y=\text { Skor Total koefisien korelasi } \\
& \Sigma \mathrm{X}=\text { skor total butir soal } \\
& \sum \mathrm{Y}=\text { skor total responden } \\
& \mathrm{n}=\text { banyak responden }
\end{aligned}
$$

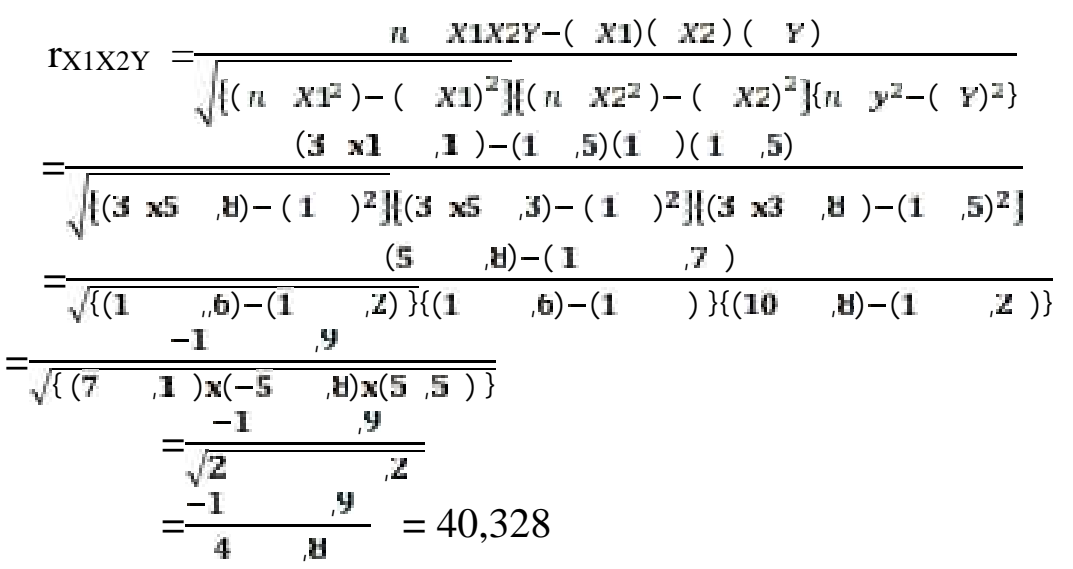

Jadi: $r$ hitung $=40,328$ dan $r$ tabel $5 \%=0,339$

Hasil perhitungan dan pengujian hipotesisi secara simultan di atas membuktikan bahwa ada pengaruh yang signifikan secara simultan sarana prasarana dan profesionalisme guru terhadap penerimaan peserta didik baru di peroleh $\mathrm{r}$ hitung $=$ 40,328 dan $r$ tabel sebesar 0,339 koefisien determinasinya sebesar 13749031,52\% yang berarti bahwa penerimaan peserta didik baru dapat ditentukan oleh sarana prasarana dan profesionalisme guru MTsN 8 Jombang yang diterima yang secara bersama-sama (simultan) sebesar 13749031,52\%,. Hasil tersebut sejalan dengan teori yang di kemukakan (Sarwindah:2016), dalam jurnalnya dengan judul Sistem Pendaftaran Siswa Baru Pada SMPN 1 Kelapa. Mengatakan bahwa manajemen sarana dan profesionalitas guru secara bersama-bersama berpengaruh signifikan terhadap penerimaan siswa baru. tersebut membuktikan sarana prasarana dan profesionalisme guru dikatakan baik dan benar bila mampu membawa peningkatan atau bertambahnya jumlah peserta didik baru. Sesuai kegunaan dan permasalahan yang telah dirumuskan bahwa kegunaan dari penelitian 
Manajemen Sarana dan Prasarana di Lembaga Pendidikan Islam Manajemen Sarana dan Prasarana di Lembaga Pendidikan Islam. Tujuan dari manajemen sarana dan prasarana pendidikan yaitu agar dapat memberikan kontribusi yang optimal terhadap proses pendidikan dalam mencapai tujuan pendidikan yang telah ditetapkan. Proses manajemen sarana dan prasarana pendidikan berkaitan erat dengan perencanaan sarana dan prasarana pendidikan, pengadaan sarana dan prasarana pendidikan islam, inventarisasi sarana dan prasarana pendidikan, pengawasan dan pemeliharaan sarana dan prasarana pendidikan dan pengahapusan sarana dan prasarana sekolah.

\section{KESIMPULAN}

Sesuai kegunaan dan permasalahan yang telah dirumuskan bahwa kegunaan dari penelitian ini adalah untuk mengetahui secara empiris pengaruh manajemen sarana dan kompetensi profesionaltas guru terhadap jumlah penerimaan siswa baru, dimana sebelumnya diidentifikasi secara parsial, baik pengaruh manajemen sarana maupun pengaruh kompetensi profesionalitas guru terhadap penerimaan peserta didik baru. Berdasarkan hasil pengujian analisis regresi dan hipotesis pada masing-masing variabel, maka penelitian ini menemukan bahwa:

1. Ho1 adalah uji hipotesis pada pengaruh variabel manajemen sarana terhadap penerimaan siswa baru, dengan hasil uji t sebesar 2.420, jika dikonsultasikan kepada t-tabel, maka diketahui bahwa t-hitung lebih besar dari t-tabel 0,385 >0.339, artinya secara parsial manajemen sarana berpengaruh secara signifikan terhadap Penerimaan Siswa Baru, maka Ho1 ditolak dan Ha1 diterima.

2. Ho2 adalah uji hipotesis pada pengaruh variabel kompetensi profesionalitas guru terhadap penerimaan siswa baru, dengan hasil uji $t$ sebesar 7,373, jika dikonsultasikan kepada t-tabel, maka diketahui bahwa t-hitung lebih besar dari ttabel, 7,373 > 0.339, artinya secara parsial kompetensi profesionalitas guru berpengaruh secara signifikan terhadap Penerimaan Siswa Baru, maka Ho2 ditolak dan $\mathrm{Ha} 2$ diterima.

3. Ho3 adalah uji hipotesis secara simultan bahwa manajemen sarana dan kompetensi profesionalitas guru keduanya berpengaruh secara signifikan terhadap penerimaan peserta didik baru. Terbukti melalui pengujian hipotesis pada pengaruh variabel kompetensi profesionalitas guru terhadap penerimaan peserta didik baru, dengan hasil uji $\mathrm{F}$ sebesar 145,0 yang dikonsultasikan kepada F-tabel, maka diketahui bahwa F-hitung lebih besar dari F-tabel 145,0 > 3,33, artinya, maka Ho3 ditolak dan Ha3 diterima.

Keberhasilan tujuan organisasi sekolah akan tercapai apabila jumlah penerimaan peserta didik baru dapat terjaga secara terus menerus. Penerimaan peserta didik baru tersebut merupakan hasil output dari semua upaya yang dilakukan oleh manajemen sekolah, diantaranya adalah melalui perbaikan sarana dan peningkatan profesionalitas guru.

Dalam mencapai tujuan organisasi sekolah manajemen sarana memiliki peranan dalam penerimaan peserta didik baru. Namun manajemen sarana tidak akan berlangsung dengan efektif apabila tidak didukung oleh stakeholders. Profesionalitas guru merupakan upaya utama di dalam menjaga kualitas sekolah, karena guru merupakan unsur utama di dalam menjalankan seluruh aspek 
manajemen sekolah.Oleh karena itu, tuntutan peningkatan kualitas guru merupakan hal yang seirama dengan upaya peningkatan prorfesionalitas guru itu sendiri.

\section{DAFTAR PUSTAKA}

Astuti, E., 2018. Menejemen Sarana Prasarana Pendidikn dalam Meningkatkan Mutu SDM (Studi Kasus di MAN 3 Madiun), Institut Agama Islam Negeri (IAIN) Ponorogo Pascasarjana.

Baharudin dan Moh.Makin. 2010. Manajemen Pendidikan Islam Transformasi menuju Sekolah/Madrasah Unggul. Malang: UIN-Maliki Press.

Epuji Astuti, 2018 Institut Agama Islam Negeri (IAIN) Ponorogo Pascasarjana Menejemen Sarana Prasarana Pendidikn dalam Meningkatkan Mutu SDM (Studi Kasus di MAN 3 Madiun)

Fitriani,C., 2012.Kompetensi Profesional Guru dalam Pengelolaan Pembelajaran di MTs Muhamadiyah Banda Aceh,Magister Administrasi Pendidikan, Pascasarjana Universitas Syiah Kuala

Jihad Asep dan Suyanto , Menjadi Guru Profesional, Jakarta: Esensi,2013,87

Nurbaiti. 2015. Manajer Pendidikan. jurnal Manajemen Sarana dan Prasarana Sekolah Volume 9. Nomor 4, Juli 2015

Pramono Harry. 2012, Pengaruh Sistem Pembinaan Sarana Prasara dan Pendidikan LatihanTerhadap Kompetensi Kinerja Guru Pendidikan Jasmani Sekolah Dasardi Kota Semarang,Jurnal Penelitian Pendidikan. Vol. 29 Nomor 1.

Suyanto dan Asep Jihad, 2013, Menjadi Guru Profesional, Jakarta: Esensi.

Sedarmayanti. 2009. Sumber Daya Manusia dan Produktivitas Kerja, Bandung:Mandar Maju.

Sarwinda. 2016. Sistem Pendaftaran Siswa Baru Pada SMPN 1 Kelapa Berbasis Web, Jurnal SISFOKOM, Volume 07, No. 02.

SedarmayantiSumber Daya Manusia dan Produktivitas Kerja, Bandung: Mandar Maju. 2009,47

Tubagus Djaber Abeng Ellong, M.Kes, MMR 2017 Fakultas Tarbiyah dan Ilmu Keguruan [FTIK] IAIN Manado. Jurnal Penidikan Islam Iqra'Vol. 11. Nomor 1 